\section{WANNA CHANGE THE WORLD? START WITH YOURSELF $^{1}$}

\section{Boonsiri Anantasate ${ }^{2}$}

\begin{abstract}
To have highly motivated students, a teacher must be motivated in teaching $\mathrm{him} /$ herself. If a teacher wants his/her student to get involved in class activities, $\mathrm{s} / \mathrm{he}$ has to become involved first.
\end{abstract}

Having been teaching English as a foreign language for more than 25 years, I find the question "How can an English class be made more interesting?" the most frequently addressed by my colleagues and counterparts from various institutions. Getting students motivated has also been a crucial, even burning, topic of discussion among the teachers attending every teachers' training course I have been conducting. Not only are language teachers concerned about the issue in question but an increasingly larger number of Thai students are expressing their needs and expectations as regards their proficiency level in the English language. While the importance of English in this fast-changing world seems obvious the question of how to teach and learn the language effectively still remains an enigma.

${ }^{1}$ This article is based on the writer's Ph.D. dissertation on a teaching and learning process to promote learners' autonomy.

${ }^{2}$ Ph.D., Associate Professor, and Director of Chulalongkorn University Language Institute (CULI).
In my long-time experience of language teaching, I have met quite a number of industrious and devoted teachers whose sole, unwavering objective has been to make their students proficient in English. What they have been doing really deserves praise. They have been working $h$ ard to inject new things into their classrooms, but at some point, most realize that all is to no avail. Among the sources of teachers' discouragement are the students' low motivation, poor co-operation and meager or almost unnoticeable improvement in their English language proficiency. So what exactly has gone wrong?

Part of a n a nswer $\mathrm{c}$ ame to mind one day while I was driving back home. At that time, S Club 7--a boy and girl band from England--became a big hit. Requests for their songs flooded almost every FM. radio station and you could hear their on air s ongs p ractically e very hour. Among these songs, I found one particularly striking. It is c alled "Gonna Change the World". Both its melody and lyrics, I thought, were invigorating as well as meaningful. Certain parts I consider miraculously relevant and thus, applicable to the revitalization of our language teaching and learning practice include the following:

"I wanna change the world

But I know I have to start with me Can you help me?"

\section{"Gonna change the world}

Gonna make it right

Gonna get down on my knees tonight

Gonna change it all

Gonna find the way

Gonna start to change the world

today" 
There is not a book that you cannot rewrite

$$
\text { and }
$$

"When something is wrong

Only we can turn it around

So give me your hand, my brother

and walk together

'Cos we've got a mountain to climb..... Change the World today..."

(For full text of the lyrics, see Appendix A.)

After listening to this song time and time again, I let my mind wander. In so doing, I managed to free my brain from rigid lines of thought, allowing it to make unusual connections. "In order to make my English class interesting, I have to start with myself. However, there are two main parties involved in this 'business venture': me and my 30 partners or allies, my students. If I could persuade them to modify their learning behavior while I take care of my teaching, will that make things different?" Enthusiastic to give this idea a try, I started planning an activity--my so-called the learners' awareness-raising strategy. I chose to launch this activity in my second meeting with the class, as part of the ice-breaking ritual. What I did was given them the full lyrics of the song "Gonna Change the World" and played the song for them. Several of them even sang along joyfully; others enjoyed the song silently while moving some parts of their body to the rhythm of the music.

When the recording came to an end, I asked each of them to express his/her personal feelings about the song. In general, they said they liked it. To the question why they found it appealing, some said that S Club 7 was currently popular, so everyone was listening to their songs. Others were interested in the meaning of the song and added that they could learn a lot from it. I then pushed the conversation a little bit further by asking them to tell the class what their favorite lines in the song were and why they liked them. Much to my surprise, I could keep the class deeply involved for almost 45 minutes. Everyone appeared genuinely motivated and expressed their firm belief that they could change the world for the better and that in order to realize that goal, they needed to change themselves first. They also added that this mission was not easy, but not impossible. With friends to help them, they believed they could succeed in whatever they wanted to do.

Realizing that it was time for me to drive my point home, I threw out my final question: "How can you apply the ideas you got from this song to making our English class more interesting?" "Be active, ask questions, participate in class more, speak English more, listen to English songs, use English more often both in and outside class, read more English, and become more interested in English" formed part of the answers. Pleased with their responses, I added that to attain the goal of making our class interesting and helping students learn more effectively, I would also change myself. An unwritten contract was then made b etween the two parties-me and the learners. We would try our best to change ourselves and then "rewrite the book." We would invest our effort, time and energy in creating a learning-promoting environment; it was a deal.

After the first session, I started looking more critically at myself and the way I taught. Why was the first session warmly received? Was it because I used a song that most of them knew and liked? Did the students feel motivated because they found the approach novel and the gist of the song 
directly relevant to their experiences? Did they find the easy-going and relaxing atmosphere appealing? To find out why, I asked the students to write a short paragraph in their learning logs under the topic "What have I learned from Gonna Change the World?" Several of my students' answers were quite encouraging. For example, one student wrote.....

\section{"I learn valuable things from the} song. I learn that everything depend on myself. I can control my life to the ways I want. I think everything can change. If I make wrong on this day, I believe that it will better tomorrow."

$$
\text { (original unedited text) }
$$

Another student wrote.....

"I learn that we are not a lone in this world. There is someone always by our side, helping when we are in trouble. Besides, I can learn that we must try to cope with the problem. Do not give up and we will find the way out. I also like the words and the music. They are beautiful."

What the students' writing reflected gave me the encouragement I needed. It implied an awareness of their role as learners, who needed to be more responsible for their own learning, their own problems and their own life. Also suggested by their answers was that they had to confront their problems and do their best to find solutions. In so doing, they were not alone; they had friends and several others who cared about them. Positive thinking that things can change for the better, to me, can play a vital role in their development into mature adults as well as in their learning.
The first time class met, besides the students' personal opinions about their ideal English class and English teachers, their expected development goals in English, and their plans for self improvement in English from their personal information forms I had asked them to fill out. Based on their responses, they wanted the teacher to give them--individuals or in groups-more chances to use English in class; they simply needed to be an important part of the show too. Some students expressed their discouragement and doubt about the way English had been taught and learned. To them, about 10-12 years of learning English failed to equip them with adequate tools for real communication. They could not write, speak and listen well e nough in the target language. Some also expected to see a more interesting, challenging, lively, flexible, relaxing and entertaining English class. My next question was how I could apply the students' ideas to my self-changing process.

Since quite a number of my students expressed their preference for the use of songs, I decided to incorporate songs thematically relevant to the main reading texts as part of the lessons to be covered. This could be initially made into a listening exercise, in which the students were asked to fill out the missing words while listening to the recording.

After that, we discussed the meaning of the song, which was then utilized as the lead into the reading text. I did not read to the students and I don't recommend reading to students. Instead, I put the students into groups of 4-5 and assigned each group a question to answer. The group members had to first scan the text quickly and locate the specific part of the text to work on to answer the assigned problem. My questions usually required them to bring into the reading task their own experiences. This 
indirectly helped reactivate their dormant knowledge of the language as regards vocabulary, spelling, grammar and writing. As they had to present their answers to class, they could also practise their speaking skills. Often, the students had questions about the words they wanted to use and how to use them in their sentences. I grasped these golden opportunities to introduce them to good English language dictionaries and showed to them how their problems could be tackled with the help of reliable and comprehensive dictionaries. During the presentation phase, I demanded the use of OHTS and full attention from the audience. I myself, of course, listened attentively, asking some questions to help the speakers clarify their points. Also, while listening, I would note down important learning points as well as errors that really needed to be corrected. T hese w ould be discussed $w$ ith the whole class later. The listening/reading/speaking tasks could then be further expanded. I usually asked the students to w rite a short p aragraph a bout what they had learned each day (which means two times a week) in their learning logs. Related outside reading was also assigned sometimes. For example, the students were asked in groups to bring to their next class one or two newspaper clippings related to the topic we had already discussed in class.

To illustrate the points mentioned above, I have also included one part of my lesson in this paper. The reading text to be covered was "The Urban Crisis" and the lead song used was "So the Story Goes" by Maria Montell. (For the song, the reading questions as well as the extended task, please see Appendices B-D.)

What I have said so far is that we need to change ourselves first in order to change the world. To have highly motivated students, we must become highly motivated teachers first. If we want our students to become involved in class activities, we must become involved first. Also remember to provide students with opportunities for them to become responsible learning partners. Of course, we must be responsible learning teachers first.

\section{Reference}

Kirn, Elaine and Pamela Hartmann. 1997. Interactions Two: A Reading Skills Book, Singapore: The McGraw-Hill Companies, Inc. 
Appendix A

\section{Gonna Change the World Artist: $S$ Club 7}

I wanna change the world......

But I know I have to start with me

Can you help me?

When your world is closin' like it's comin' at ya

When you're in the darkest corner

I'm the one who'll come and catch ya

When your life is wanderin'

Down some nowhere highway

Try a different point of view and

Do your best to see things my way

Lookin' down there is brother facin' brother

Dyin' one by one

But from the ground you can look up at the stars

And see the words "I love you" painted high above you......

*Gonna change the world

Gonna make it right

Gonna get down on my knees tonight

Gonna change it all

Gonna find a way

Gonna start to change the world today*

There is not a book that you cannot rewrite

When you're in the darkest corner

All you do is shine your light and

When the other guy
Is bigger than the sky

Just before he's gonna hit ya

You can always try a smile 'cos

All around hear a million lonely people

As they say, "Goodbye"

Yet there's the sound of a world that's full of

laughter

Because now I know I'm better at "Hello" and *...........* (1 time)

When something is wrong

Only we can turn it around

So give me your hand, my brother and walk together

'Cos we've got a mountain to climb......

Change the world today

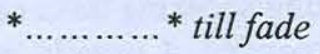




\section{Appendix B}

\section{And so the story goes \\ Artist: Maria Montell}

She's on a 1) road alone

Traveling, traveling, traveling alone

She loves to laugh, she loves to live, and she loves to

Love

She 2)

To find the things 3) , her family

From the window in her house 4)

\section{Chorus 1}

This small town girl 5)

To reach her dreams 6)

Chorus 2

$$
\text { Ay..ya..ya.. }
$$

And so the story goes

Di-da-di

$D i-d a-d i$

Di-da-di-da-di-da-di-da-di...... (2 times) She 7)

But found 8)

One winter's day

She saw her rosebuds 9) in the

And then 10)

$$
\text { welfare ines }
$$

Strolling, strolling, strolling alone

She hated some, she needed some, and she loved some.

Chorus 2/ Chorus 1/ Chorus 2...... until fade.

\section{Appendix C}

\section{Reading Questions}

In most developing/underdeveloped countries, a large number of people move from the rural a reas to big cities. What has caused the exodus from the countryside to the cities? Base your answers on the text and your personal experience.

What generally occurs as a result of an influx of people into big cities? Base your answers on the text and your personal experience.

The text also suggests some solutions to urban problems. What are they? Have your group members got any possible answers to such problems?

\section{Appendix D}

\section{Extended Task}

Next time please bring to class some newspaper clippings concerning problems in big cities. 